\title{
Exposure to Respirable Particulates and Silica in and around the Stone Crushing Units in Central India
}

\author{
Krishnendu MUKHOPADHYAY ${ }^{1 *}$, Ayyappan RAMALINGAM${ }^{1}$, Raghunathan RAMANI', \\ Venkatesan DASU', Arulselvan SADASIVAM1, Pramod KUMAR ${ }^{2}$, \\ Shyam Narayan PRASAD ${ }^{2}$, Sankar SAMBANDAM ${ }^{1}$ and Kalpana BALAKRISHNAN ${ }^{1}$
}

\author{
${ }^{1}$ Department of Environmental Health Engineering, Sri Ramachandra University, Chennai - 600 116, India \\ ${ }^{2}$ Environment System Branch, Development Alternatives, New Delhi-110 016, India
}

Received April 19, 2010 and accepted July 5, 2010

Published online in J-STAGE December 16, 2010

\begin{abstract}
Stone crushing unit workers suffer from particulate matters and respirable silica at work and in their residents nearby. The present study was undertaken to evaluate the area and personal exposure concentration of respirable particulate matters and silica in workplaces and in surrounding villages. $\mathbf{P M}_{10}, \mathbf{P M}_{4}$ and $\mathbf{P M}_{2.5}$ were considered for unit area measurement and $\mathbf{P M}_{4}$ and $\mathbf{P M}_{2.5}$ were considered for personal exposure measurements. The ambient $\mathbf{P M} 10$ and indoor respirable particulate sampling and analyses were carried out in two neighboring villages adjacent to a cluster of 100 stone crushing units in central India. The study was conducted in two years with varied seasons to provide baseline data on the existing particulate concentration with and without control intervention. Monitoring and analytical criteria were fulfilled according to the National Institute for Occupational safety and Health (NIOSH), USA protocol. The study reports the higher particulates and respirable silica with respect to the national and international guidelines in and around the study units. However, in nearby villages, the particulate concentrations and silica were comparatively less. An innovative dust abatement dry engineering control system was installed as a pilot work to reduce dust emission from the unit and the results afterward were found to be encouraging.
\end{abstract}

Key words: Respirable particulate matters, Respirable silica, Spatial dispersion, Dust abatement

\section{Introduction}

Stone quarrying and crushing industries are an important class of "essential industry" that supplies the raw material for many large scale construction and transport related projects. During the stone crushing process, large size boulders in the range between $200-300 \mathrm{~mm}$ are taken from the mine and are unloaded from almost 25 feet height into the mouth of the primary crusher machine of the unit where these are broken into smaller pieces. These pieces are taken through a conveyor belt to disintegrator which produces powder out of these

*To whom correspondence should be addressed.

E-mail: teestamuk@rediffmail.com small granules followed by size-wise separation through vibrator. Finally different sized chips are carried to different product sites and a hoper is served as the dust collector. Generally, final products are of three different size granules, e.g., 6, 12 and $20 \mathrm{~mm}$. By this process, large amount of free silica is produced which increases the risk of silicosis and silico-tuberculosis ${ }^{1)}$. This huge amount of micro size dust is the major concern for personal as well as community health. Generally, stone crushing industries are located adjacent to the highways and nearby communities for the sake of convenient transport facilities. Mainly rural, migrant, untrained and poor workers are engaged in this unorganized sector where the focus on workers health and socioeconomic conditions are generally neglected. Some workers reside 
in the poor ventilated small houses within the unit area, some come from the nearby villages and very few from the far localities. For the nearby resident workers, especially who reside within the unit area, both environmental and occupation exposure coexist and they are more at risk of health abnormalities related to stone dust.

About $12 \%$ of the earth's crust consists of free silica, mostly quartz. "Free Silica" is nothing but $\mathrm{SiO}_{2}$ which is most fibrogenic. Airborne particles with less than 7 microns are capable of reaching the alveolar region of respiratory system that can cause silicosis. These particles are commonly known as "respirable" particles. The silica particles induce fibrosis in the lungs, i.e. the normal lung tissue is replaced by non-functioning fibrous tissue. The fibrosis in non-complicated or simple silicosis is in the form of fine nodules varying in size from $1.5-3.0 \mathrm{~mm}$, developing later into pulmonary massive fibrosis $^{2)}$.

The stone mined in the Central Indian area is generally 'slab stone'. An environmental and medical survey conducted by the National Institute of Occupational Health (NIOH), Ahmedabad, India for this type of industry revealed that the total and respirable dust concentrations during the process of stone cutting were $22.4 \mathrm{mg} / \mathrm{m}^{3}$ and $1.6 \mathrm{mg} / \mathrm{m}^{3}$, respectively. Examination of 125 stone cutters showed that the prevalence of silicosis and tuberculosis were $22 \%$ and $48 \%$ respectively. The average duration of dust exposure for the development of silicosis was 12 to $15 \mathrm{yr}$. The total and respirable dust levels after installation of the control device, which operates on the principle of enclosure, were $3.4 \mathrm{mg} / \mathrm{m}^{3}$ and $0.8 \mathrm{mg} / \mathrm{m}^{3}$, respectively ${ }^{3}$.

Exposure to respirable dust coming out from stone crushing units may create adverse health effects, chief among them being pneumoconiosis ${ }^{4)}$. The Union Ministry of labour and the United States Occupational Safety and Health Administration (OSHA) have established a respirable dust exposure limit of $5.0 \mathrm{mg} / \mathrm{m}^{3}$ ). The permissible exposure limit (PEL) for respirable crystalline silica, regulated under Indian Factories Act $(1948)^{6)}$ accounts for the variable toxicity of respirable dust proportional to the concentration of quartz and crystobalite present in the dust. Recommended Exposure Limit (REL) by NIOSH for crystalline silica, quartz and crystobalite is $0.05 \mathrm{mg} / \mathrm{m}^{3}$ as a time weighted average (TWA) for up to a 10 -h workday during a $40 \mathrm{~h}$ work week.

Earlier studies have reported a high prevalence of silicosis in other type of industrial sectors ${ }^{7,8)}$ but a little is known about the respirable dust exposure from stone crushers in developing countries in Asia ${ }^{9-11)}$. Some of these studies emphasized on the dust exposure either by managing workers consent or by 'proxy personal sam- pling'. However, in all those studies the job activity pattern of the workers, dry processed control strategies or comparative dust concentration between the sampling with intervention and without intervention were not considered.

Based on the participatory approach, four phase air quality monitoring study was carried out between March 2007 and August 2008. Units were reported to have the crushing capacities in the range of 800-1,200 cubic feet/ hour causing the release of huge amount of dust as the byproduct. Analytical measurements employed NIOSH Method 0600 for gravimetric analysis of respirable dust. The respirable silica concentration was included to reveal an important input for the design of sustainable and cost effective interventions which could be used as a major risk communication tool while building capacities of local medical practitioners. The NIOSH Method 7500 was used for quartz analysis in respirable dust samples. The measured quartz content of respirable dust showed the range between 7 and 24\%.

The results of the study will shed light on special challenges in implementing basic occupational safety and health improvements in marginalized industrial sectors within resource poor settings. The sharing of research results will provide an opportunity to elicit inputs from other occupational safety and health experts for risk management in these communities.

Installation of the dust abatement engineering system in the crushing unit was one of the major concerns of the study. Fourth phase study was conducted in an entirely different climatic condition. Time to time rain, wet boulders, frequent failure of electricity supply, inadequate workers attendance and frequent breakdown of crushing machine made this study a little different as compared to other three phase studies. However, the comparative assessment of respirable particulates not only provided the sense of seasonal variations but also supplied encouraging results for the future prospect of commissioning the dust abatement system in other crushing units in the region.

Without using water sprinkler system as the dust control tool, an alternate cost effective and sustainable dust control system was commissioned in one of the study units to assess the reduction percentage of respirable dust emission from the unit sources. Though the estimated reduction percentage in one phase study didn't exceed $50 \%$, yet it was found encouraging. Only some minor mechanical corrections of the control assembly set up could make drastic potential change in result output. The deposition of dust in the dust collecting chamber was found to be filled rapidly through the mechanism of cyclonic device and bag-filter assembly. Meteorological parameters like temperature, wind direc- 
tion and speed were assessed time to time during the monitoring process. All these parameters have significant effects on the workers exposure to respirable dust.

The main objective of this study was to estimate the personal exposure of the unit workers to respirable dust \& silica and to assess the community environment nearby the stone crushing cluster. The other purpose was to motivate unit owners to install cost-effective and sustainable dust control device as a part of participatory approach to establish a model of dust abatement program in this sector.

\section{Subjects and Methods}

A total of 359 samples were collected from selected crushing units and communities in the form of $\mathrm{PM}_{10}$, $\mathrm{PM}_{4}$ and $\mathrm{PM}_{2.5}$ particulate matters in four distinct climatic conditions within two years. The dust control system was installed for jaw crushers and vibrators. Particulate concentrations were estimated in three distinct climatic conditions without installing the dust abatement system, but the fourth and final phase sampling was conducted to collect the particulate mass by with- and without run of the control system. Different types of respirable dust samples like unit area, personal and community samples were selected for the determination of respirable dust concentration gravimetrically by NIOSH method number 0600 and quartz concentration according to NIOSH method number $7500^{12)}$. $\mathrm{PM}_{10}$ particulate matters were monitored using the Envirotech sampler (Model- $\mathrm{APM}_{4} 60 \mathrm{BL}$ ) with the flow rate ranging between $0.9-1.1 \mathrm{~m}^{3} \mathrm{~min}^{-1} . \mathrm{PM}_{4}$ and $\mathrm{PM}_{2.5}$ particulates were monitored using SKC pump (Model-224-PCXR8) with the flow rate ranging from $2.51 \mathrm{~min}^{-1}$ to $3.51 \mathrm{~min}^{-1}$ along with aluminum and BGI cyclone, respectively. Respirable dust samples were collected on $37 \mathrm{~mm}$ PVC filter (pore size $5 \mu \mathrm{m}$ ) for $\mathrm{PM}_{4}$ or on $37 \mathrm{~mm}$ cellulose acetate filters (pore size $0.8 \mu \mathrm{m}$ ) for $\mathrm{PM}_{2.5}$ particulates. A rotameter was used to calibrate flow rate of the samplers. For area measurements, $\mathrm{PM}_{10}$ samplers were commissioned at a height of $1.5 \mathrm{~m}$ above the floor in both the locations of units and communities whereas for $\mathrm{PM}_{4}$ and $\mathrm{PM}_{2.5}$ samplers, the height was kept around $4.5-5$ feet so as to match the breathing zone height of the peoples. For personal sampling, the cyclone was attached at the breathing zone of the worker in order to monitor respirable dust. The filters were conditioned in desiccators for $24 \mathrm{~h}$ at $25^{\circ} \mathrm{C}$ and weighed before and after testing to determine the deposited dust. Cahn Electronic micro balance (sensitivity $0.001 \mathrm{mg}$, Model: C-34, Cahn, Germany) was used as the weighing system. Samplers were pre- and post-calibrated to ensure recommended pump flow rates during sampling. Filters collected with samplers that did not meet this criterion due to pump failure were rejected.

Respirable silica dust concentrations were recorded in worksite locations of the crushing units as well as in indoor locations of the selected communities. Different category samples like, unit-area samples, personal samples of workers, and community area-kitchen \& bedroom samples were analysed to assess respirable silica dust concentrations.

For respirable silica analysis, selected dust samples were sent to an accredited analytical laboratory (Bureau Veritas North America, Inc.) in the U.S. for analysis. The instrumental technique of X-Ray Diffraction Spectrometry (XRD) employing NIOSH Method 7500 was used for analyses of crystalline silica in respirable particulates.

The quotient of the respirable dust exposure and OSHA PEL was detrmined to establish the degree of compliance with the PEL. The OSHA $8 \mathrm{~h}$ TWA was calculated using the formula provided below:

Quartz (in terms of respirable dust) $=$

$$
\frac{10}{\% \text { respirable quartz }+2} \mathrm{mg} / \mathrm{m}^{3}
$$

Figure 1 shows the plant layout with different dust monitoring locations. Black circles are depicted as the area monitoring locations for $\mathrm{PM}_{4}$ and $\mathrm{PM}_{2.5}$ dust samplers whereas small black squares represents the locations for $\mathrm{PM}_{10}$ particulates.

Figure 2 shows the dust control system commissioned near primary jaw crusher and primary siever where cyclonic mechanism and bag filter assembly are seen alongwith the dust collecting chamber. The design of the dust control system was based on the mitigation process of major dust emitting sources like primary siever, secondary siever, primary crusher, secondary crusher and tertiary crusher. Main system components include cyclone separator, blower with electric motor, suction hood, duct-line, enclosure and dust collection chamber. The control system cost was about four hundred thousand Indian Rupees containing 20 Horsepower running capacity. The suction device is connected to all selected dust sources individually and the sucked dust is conveyed by the suction hood and duct line, reaches to the cyclone separator and bag filter and ultimately it is deposited into the dust collection chamber from where the deposited dust is collected. During the post intervention study in the unit, it was observed huge amount of dust settled inside the chamber while running the installed engineering control system. It indicates that the use of dust abatement system was encouraging. 


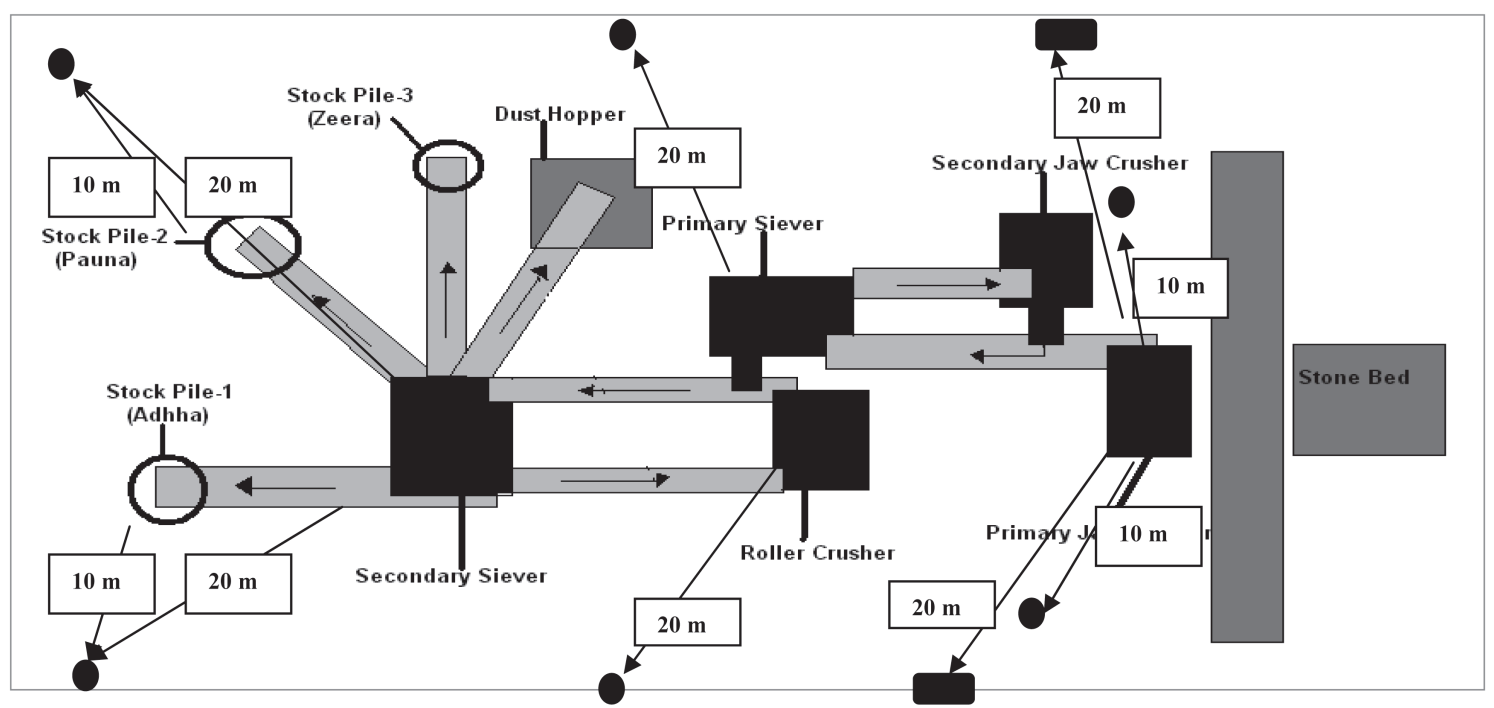

Fig. 1. The plant layout with different dust monitoring locations.

a. Black-circles are depicted as the area monitoring locations for $\mathrm{PM}_{4}$ and $\mathrm{PM}_{2.5}$ dust samplers.

b. Small black-squares represent the locations for $\mathrm{PM}_{10}$ particulates.

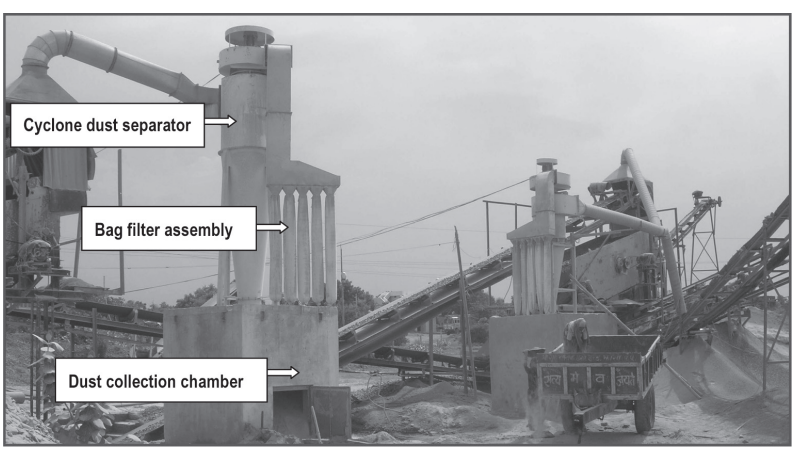

Fig. 2. The dust control system.

Commissioned near primary jaw crusher and primary siever where cyclonic mechanism and bag filter assembly are seen along with the dust collecting chamber.

\section{Results}

First three phase studies were conducted in the month of March 2007, December 2007 and February 2008. Both, climatic conditions as well as unit owners' consent were taken into account for smooth conduct of the study. Table 1 shows the average unit area particulate concentrations for $\mathrm{PM}_{10}, \mathrm{PM}_{4}$ and $\mathrm{PM}_{2.5}$. Since the permissible standards in terms of individual particulate matter like $\mathrm{PM}_{10}, \mathrm{PM}_{4}$ and $\mathrm{PM}_{2.5}$ in industrial setting are still awaited, it is not worthy to compare the permissible limit of all the selected particulates with a single reference of OSHA or ACGIH limits to assess the industry situation. On the other hand, it has been observed that the percentage of quartz in all representative samples analyzed for silica content were found to
Table 1. Average area concentration (in $\mathrm{mg} / \mathrm{m}^{3}$ ) for $\mathrm{PM}_{10}, \mathrm{PM}_{4}$ and $\mathbf{P M}_{2.5}$ of three selected stone crushing units

\begin{tabular}{cccc}
\hline Unit & $\begin{array}{c}\mathrm{PM}_{10} \\
(\mathrm{~N}=78)\end{array}$ & $\begin{array}{c}\mathrm{PM}_{4} \\
(\mathrm{~N}=46)\end{array}$ & $\begin{array}{c}\mathrm{PM}_{2.5} \\
(\mathrm{~N}=23)\end{array}$ \\
\hline 1 & $10.34(24)$ & $3.11(12)$ & $1.34(6)$ \\
2 & $19.49(31)$ & $7.40(21)$ & $1.64(9)$ \\
3 & $12.00(23)$ & $6.33(13)$ & $0.93(8)$ \\
\hline
\end{tabular}

- OSHA-PEL and ACGIH-TLV for respirable dusts are $5.0 \mathrm{mg} / \mathrm{m}^{3}$ and $3.0 \mathrm{mg} / \mathrm{m}^{3}$, respectively for $0 \%$ quartz samples.

- EPA - National Ambient Air Quality Standards (NAAQS): $0.15 \mathrm{mg} / \mathrm{m}^{3}$ (24 h averaging time for $\left.\mathrm{PM}_{10}\right)$ and $0.015 \mathrm{mg} / \mathrm{m}^{3}$ (Annual arithmetic average for $\mathrm{PM}_{2.5}$ ).

- National Ambient Air Quality Standards (India): $0.12 \mathrm{mg} / \mathrm{m}^{3}$ (annual average) and $0.15 \mathrm{mg} / \mathrm{m}^{3}$ (24 h average) respirable dust (less than 10 micron size) respectively in industrial area.

be between $7 \%$ and $24 \%$, therefore the straightforward reference of $3 \mathrm{mg} / \mathrm{m}^{3}$ as recommended by ACGIH is meaningless here. But, to assess the harmful situations at worksites of selected stone crushing units the available national and international guidelines or standards for $\mathrm{PM}_{10}, \mathrm{PM}_{4}$ and $\mathrm{PM}_{2.5}$ have been cited below the Table 1 as footnote considering the size fraction of particulates only but still results show alarming situation.

Table 2 shows the average $\mathrm{PM}_{10}$ concentration in ambient air while average $\mathrm{PM}_{4}$ and $\mathrm{PM}_{2.5}$ concentrations in indoor air condition for two different study communities. In this study, the average ambient $\mathrm{PM}_{10}$ concentrations exceeds far from the NAAQS and WHO limits. On the other hand, individual indoor limit of $\mathrm{PM}_{4}$ and $\mathrm{PM}_{2.5}$ concentrations are not yet standardized internationally. 
Table 2. Average ambient $\mathbf{P M}_{10}$, indoor $\mathbf{P M}_{4} \& \mathbf{P M}_{2.5}$ concentrations (in $\mathrm{mg} / \mathrm{m}^{3}$ ) in two selected communities

\begin{tabular}{cccccc}
\hline Village & $\begin{array}{c}\mathrm{PM}_{10} \\
(\mathrm{~N}=21)\end{array}$ & $\begin{array}{c}\text { NAAQS, } \\
2008\end{array}$ & $\begin{array}{c}\mathrm{PM}_{4} \\
(\mathrm{~N}=31)\end{array}$ & $\begin{array}{c}\mathrm{PM}_{2.5} \\
(\mathrm{~N}=06)\end{array}$ & $\begin{array}{c}\text { No permissible } \\
\text { standard in } \\
\text { indoor }\end{array}$ \\
\cline { 1 - 5 } 1 & $0.77(11)$ & $0.15 \mathrm{mg} / \mathrm{m}^{3}$ & $0.50(17)$ & $0.28(04)$ & $\begin{array}{c}\text { condition } \\
2\end{array}$ \\
\hline
\end{tabular}

Table 3. Average personal exposure concentration of the workers to respirable particulates (in terms of $\mathrm{PM}_{4}$ ) in three selected stone crushing units

\begin{tabular}{lccc}
\hline Workers' category & $\mathrm{N}$ & $\begin{array}{c}\text { Average elapsed time } \\
(\mathrm{min})\end{array}$ & $\begin{array}{c}\text { Average } \mathrm{PM}_{4} \\
\left(\mathrm{mg} / \mathrm{m}^{3}\right)\end{array}$ \\
\hline Helper (Male) & 16 & 182 & 6.29 \\
Helper (Female) & 09 & 174 & 6.84 \\
Loader (Male) & 10 & 179 & 4.51 \\
Loader (Female) & 02 & 92 & 6.62 \\
Feeder (Male) & 04 & 172 & 8.15 \\
\hline
\end{tabular}

Table 5. Comparative average area concentrations of $\mathbf{P M}_{10}, \mathbf{P M}_{4}$ and $\mathbf{P M}_{2.5}$ in selected units with and without dust control system

\begin{tabular}{cccc}
\hline Particulate size & $\begin{array}{c}\text { Conc. }\left(\mathrm{mg} / \mathrm{m}^{3}\right) \\
\text { without control } \\
(\mathrm{N}=34)\end{array}$ & $\begin{array}{c}\text { Conc. }\left(\mathrm{mg} / \mathrm{m}^{3}\right) \\
\text { with control } \\
(\mathrm{N}=36)\end{array}$ & $\begin{array}{c}\% \\
\text { Reduction }\end{array}$ \\
\hline $\mathrm{PM}_{10}$ & $6.32(09)$ & $5.85(09)$ & 7.43 \\
$\mathrm{PM}_{4}$ & $2.43(11)$ & $1.26(13)$ & 48 \\
$\mathrm{PM}_{2.5}$ & $1.77(14)$ & $1.26(14)$ & 29 \\
\hline
\end{tabular}

Table 4. Varied permissible exposure limits for silica in terms of respirable dust with respect to varied percentage of respirable quartz

\begin{tabular}{lccccc}
\hline \multicolumn{1}{c}{ Sample Type } & $\mathrm{N}$ & $\begin{array}{c}\text { Average } \\
\text { respirable } \\
\text { dust conc. } \\
\left(\mathrm{mg} / \mathrm{m}^{3}\right)\end{array}$ & $\begin{array}{c}\text { Average } \\
\text { respirable } \\
\text { quartz conc. } \\
\left(\mathrm{mg} / \mathrm{m}^{3}\right)\end{array}$ & $\begin{array}{c}\text { Average } \\
\text { respirable } \\
\text { quartz } \%\end{array}$ & $\begin{array}{c}\text { OSHA-TWA } \\
\text { permissible } \\
\text { exposure limits } \\
\left(\mathrm{mg} / \mathrm{m}^{3}\right)\end{array}$ \\
\hline Unit area & 11 & 12.59 & 1.43 & 10.98 & 0.77 \\
Unit personal & 09 & 13.42 & 1.37 & 09.52 & 0.86 \\
Community indoor & 09 & 0.27 & 0.03 & 11.94 & 0.71 \\
\hline
\end{tabular}

Table 3 shows the personal exposure concentration of the unit workers to respirable dust $\left(\mathrm{PM}_{4}\right)$. Different categories of workers e.g., helper, loader and feeder, were engaged for personal sampling and almost all categories of workers were exposed to respirable dust phenomenally. To avoid the overload on filter papers, the visual dust around samplers were noticed critically and based on the same the sampling periods had to change per filter which ranged between $30 \mathrm{~min}$ and 338 min. The average $\mathrm{PM}_{4}$ exposure concentrations for all selected categorical workers were found to be between $4.51 \mathrm{mg} / \mathrm{m}^{3}$ and $8.14 \mathrm{mg} / \mathrm{m}^{3}$ which were alarmingly higher than any standard supposed to compare nationally or internationally. As, all randomly selected samples for silica analysis contained quartz and rock used for all samples were from the same quarry, it was believed that for all other unit samples the quartz percentages would obviously above $0 \%$. Considering this condition, ACGIH-TWA 2008 recommendation of $0.025 \mathrm{mg} / \mathrm{m}^{3}$ for respirable silicacan be compared to assess the depth of dangerous exposure situation for the workers.

From the Table 4 it is seen that the respirable silica concentrations in indoor samples collected from kitch- ens and bedrooms of the selected households from two communities were lesser with respect to other two types of samples like unit area and unit personal. As per OSHA-TWA limits, the permissible limits vary according to the value of respirable quartz percentage and in this study unit area and personal samples exceed the corresponding permissible limits. It should also be mentioned that even though the dust containing $100 \%$ quartz, the limit value for silica would be $0.098 \mathrm{mg} / \mathrm{m}^{3}$. This is significantly higher than recommendations of the ACGIH-TWA 2008 that sets the limit value in terms of respirable quartz dust at $0.025 \mathrm{mg} / \mathrm{m}^{3}$.

As already mentioned, fourth phase study was conducted in different kind of climatic condition with sometimes sunny, sometimes cloudy and sometimes rainy weather. In this study condition, comparative concentrations of different sized particulates were determined to assess the average respirable dust concentration of the unit with and without dust control system. Table 5 shows the comparative concentrations of individual $\mathrm{PM}_{10}, \mathrm{PM}_{4}$ and $\mathrm{PM}_{2.5}$. Reduction percentages of dust were found to be $7.43 \%, 48 \%$ and $29 \%$ for $\mathrm{PM}_{10}$, $\mathrm{PM}_{4}$ and $\mathrm{PM}_{2.5}$, respectively. Comparatively lesser dust 
Table 6. Average area concentration (in $\mathrm{mg} / \mathrm{m}^{3}$ ) for $\mathbf{P M}_{4}$ and $\mathbf{P M}_{2.5}$ of other two stone crushing units without dust abatement system

\begin{tabular}{cccc}
\hline Unit & $\begin{array}{c}\mathrm{PM}_{4} \\
(\mathrm{~N}=12)\end{array}$ & $\begin{array}{c}\mathrm{PM}_{2.5} \\
(\mathrm{~N}=14)\end{array}$ & $\begin{array}{c}\text { NAAQS } \\
\text { (EPA) }\end{array}$ \\
\hline 2 & $1.03(10)$ & $1.40(10)$ & $\begin{array}{c}0.15 \mathrm{mg} / \mathrm{m}^{3} \mathrm{PM}_{10}(24 \mathrm{~h} \mathrm{avg.)} \\
\text { and } 0.015 \mathrm{PM}_{2.5} \mathrm{mg} / \mathrm{m}^{3} \\
\text { (Annual arithmetic avg.) }\end{array}$ \\
\hline
\end{tabular}

Table 7. Fourth phase average ambient $\mathbf{P M}_{10}$ and indoor $\mathrm{PM}_{4}$ concentrations (in $\mathrm{mg} / \mathrm{m}^{3}$ ) in two selected communities

\begin{tabular}{ccccc}
\hline Village & $\begin{array}{c}\mathrm{PM}_{10} \\
(\mathrm{~N}=07)\end{array}$ & $\begin{array}{c}\mathrm{PM}_{4} \\
(\mathrm{~N}=10)\end{array}$ & $\begin{array}{c}\text { NAAQS, } \\
2008\end{array}$ & $\begin{array}{c}\text { WHO, } \\
2005\end{array}$ \\
\hline 1 & $0.06(4)$ & $0.58(6)$ & 0.15 & 0.02 \\
2 & $0.09(3)$ & $0.17(4)$ & 0.15 & 0.02 \\
\hline
\end{tabular}

reduction percentage for $\mathrm{PM}_{10}$ might be due to rainy weather at the time of sampling, which helped the particulates to be settled on the ground by trapping moisture from the environment.

To assess the situation in other two units without dust control measure, it was found that the average concentration values for both the type of particulates were relatively lower in comparison to the average values of all the three units in other three seasons. Table 6 shows the average respirable dust concentrations of two units in final phase of the study. This study has been conducted in cloudy weather, with frequent drizzling, the average concentrations of respective dusts were found to be relatively lower than the other four phases study. The average values were taken from the number of samples written in the adjacent parenthesis.

Community sampling was also carried out in the fourth phase study. Table 7 shows the average ambient $\mathrm{PM}_{10}$ concentration as well as indoor $\mathrm{PM}_{4}$ concentration. It is interesting to note that the average ambient value was comparatively lesser than the average indoor value.

\section{Discussion}

In this study it was observed that the higher concentration of dust exposure occurred in winter months of the year. On the other hand, downwind faced samples were found higher dust deposition than the upwind sampling. In most of the cases required timing for sampling process was not possible due to frequent shut down of the units for various administrative as well as mechanical reasons in this type of industrial sector. The level of exposure experienced by unit workers is a function of the environment, the receptors, and other resulting interactions between the two. Even though the objective of personal sampling was to assess TWA exposure which would require $8 \mathrm{~h}$ continuous monitoring in the workplace but working pattern of the workers no worker was found working $8 \mathrm{~h}$ continuously within $20 \mathrm{~m}$ periphery of the unit throughout the entire study. For all four individual phases of the study, respirable particulate exposure concentrations of $2.85 \mathrm{mg} / \mathrm{m}^{3}$ for a maximum available elapsed time of $338 \mathrm{~min}$, $10.23 \mathrm{mg} / \mathrm{m}^{3}$ for a maximum available elapsed time of $295 \mathrm{~min}, 1.73 \mathrm{mg} / \mathrm{m}^{3}$ for a maximum available elapsed time of $251 \mathrm{~min}$ and $0.136 \mathrm{mg} / \mathrm{m}^{3}$ for a maximum available elapsed time of $214 \mathrm{~min}$ were measured for helpers, loaders and feeders. Female subjects were also taken into account during personal monitoring.

Night shift running of the crushers was found very irregular. During night shift duty, normally the worker would not agree upon wearing personnel samplers because of the excess workload they had in the night shift due to lesser no. of workers in that shift. However, apart from this type of rigid mindset, on special request, it was possible to have some personal sampling where the TWA exposure concentrations ranging from $1.98-2.84 \mathrm{mg} / \mathrm{m}^{3}$, below Threshold Limit Value (TLV).

While comparing ambient with indoor data in communities during the last phase it was observed that the average indoor concentrations were higher than the ambient one. This might be due to the contribution of biofuels in the household who used to use wood, kerosene and cow-dung cake during their food preparation. It was also supported by respective higher kitchen dust concentration with respect to bedroom concentration of respirable particulates. This was also attributed by the results of silica concentration which was very less as compared to other particulate concentrations measured in this study.

Normally, when the crusher unit runs, the surrounding area becomes too hazy to have a clear view. Initially, when the control assembly started functioning during crushing operation, the visibility in the crushing area improved phenomenally. By open eye observation, it was supposed to have a drastic reduction of particulate dust level in the area. However, out of three distinct size particulates, namely, $\mathrm{PM}_{10}, \mathrm{PM}_{4}$ and $\mathrm{PM}_{2.5}$, for none the system could show more than $50 \%$ dust reduction might be because of inadequate area coverage of machine or might be due to lack of training of the machine operators. Inadequate output efficiency of the machine could not be avoided as the tolerable limit of the pressure caused by the giant boulders crushed by crushing machines was not tested before the experiment. Sometimes, emission of tiny dust particles was observed over the cyclone dust separators indicated the 
higher pressure than the suction capacity of the system. Therefore, improvement of suction capacity of the suppression system might be the critical point in the future modification process. The overflow of tiny dust particles from the head of the cyclone dust separator was more when the crushing machine would run in full fledge. But, within the restricted budgetary dust control system, the result achieved so far was encouraging for the area where scarcity of water restricted the use of water sprinkler system in the dust abatement process.

It is evident that the concentrations of respirable particulates in the units were found higher than the permissible limits prescribed by ACGIH or OSHA. Lesser concentration of respirable silica in the indoor samples of nearby communities indicates more contribution of particulates emitted by bio-fuels than the crushing units. Less efficiency than the expectation from the dust abatement dry control system might be due to some lacunae on mechanical device of the whole system assembly or due to the covering area is insufficient with respect to the real need.

\section{Acknowledgements}

The authors express their sincere thanks to the International Development Research Centre (IDRC), Canada for providing financial support during the project. The authors are also thankful to Dr. K. Vijaya Lakshmi, Mr. George S Sharma and Mr. Raghwesh Ranjan, Development Alternatives (DA), New Delhi, India for their cordial cooperation to meet the field requirements of the study.

\section{References}

1) Bahrami AR, Golbabai F, Mahjub H, Qorbani F, Aliabadi M, Barqi M (2008) Determination of expo- sure to respirable quartz in the stone crushing units at Azendarian-West of Iran. Ind Health 46, 404-8.

2) Kashyap SK (1994) Occupational pneumoconiosis and tuberculosis. Ind J Tub 41, 74.

3) NIOH Annual Report, India, 1986-87. NIOSH, Cincinnati.

4) Zenz C, Dickerson OB, Horvath EP (Eds.) (1994) Reproductive toxicology and occupational exposure. In: Occupational Medicine, 836-69, Mosby, St Louis.

5) Occupational Safety and Health Administration (1990) Table Z-1 Limits for Air Contaminants:1910.1000. US Dept. of Labor, Washington, DC.

6) The Tamil Nadu Factories Rules, 1950; The Tamil Nadu factories (welfare officers) Rules, 1953 and Short Notes of Cases. In: The Factories Act, 1948 (63 of 1948), 21st Ed., Madras Book Agency, Chennai.

7) Dion C, Dufrense A, Jacob M, Perrrault G (2005) Assessment of exposure to quartz, cristobalite and silicon carbide fibres (whiskers) in a silicon carbide plant. Ann Occup Hyg 49, 335-43.

8) Bang BE, Suhr H (1998) Quartz exposure in the slate industry in Northern Norway. Ann Occup Hyg 42, 557-63.

9) Sivacoumar R, Jayabalou R, Swarnalatha S, Balakrishnan K (2006) Particulate matter from stone crushing industry: size distribution and health effects. Jounal of Environmental Health Engineering 132, 405-14.

10) Gottesfeld P, Kephart JW, Balakrishnan K, Rinehart $\mathrm{R}$ (2008) Reduction of respirable silica following the introduction of water spray applications in Indian Stone Crusher Mills. Int J Occup Environ Health 14, 94-103.

11) Semple S, Green DA, McAlpine, Cowie H, Seaton A (2010) Exposure to particulate matter on an Indian stone crushing site. Occup Environ Med 65, 300-5.

12) National Institute for Occupational Safety and Health (NIOSH) (1994) METHOD 7500 dated 15 March 2003, manual of analytical methods, NIOSH, Cincinnati. 